Reprod. Nutr. Dévelop., 1985, 25 (5), 919-927.

\title{
Studies of hormone patterns during the oestrous cycle of beef cows
}

A. R. PETERS (1)

AFRC Research Group on Hormones and Farm Animal Reproduction, University of Nottingham, School of Agriculture,

Sutton Bonington Loughborough, Leicestershire (GB).

Summary. Hormone patterns in blood plasma were examined in relation to the bovine oestrous cycle in two experiments. During the luteal phase $\mathrm{LH}$ pulse frequency was low (23 pulses per $8 \mathrm{~h}$ ). There were no consistent correlations between LH, FSH and progesterone concentrations. During luteolysis, falling progesterone concentrations were accompanied by an increase in oestradiol- $17 \beta$ concentrations, $\mathrm{LH}$ concentrations and $\mathrm{LH}$ pulse frequency, the latter being almost one pulse per hour on the day before the preovulatory surge.

\section{Introduction.}

An understanding of the natural hormone events during the ovarian cycle is a pre-requisite for the ability to control it accurately by pharmacological means.

Plasma LH concentrations are low for most of the bovine oestrous cycle with a peak or surge of secretion occurring at about the time of oestrus (Swanson and Hafs, 1971 ; Hansel, Concannon and Lukaszewska, 1973 ; Christensen, Hopwood and Wiltbank, 1974). Although further smaller peaks in plasma LH concentrations during the luteal phase have been reported (Schams and Karg, 1969 ; Henricks, Dickey and Niswender, 1970 ; Snook, Saatman and Hansel, 1971), more detailed observations have since shown that, as in other species, episodes of LH secretion occur regularly throughout the cycle and that their frequency and amplitude appear to be dependent on the stage of the cycle (Rahe et al., 1980). A peak in plasma FSH concentrations also occurs at oestrus coinciding with the $\mathrm{LH}$ surge (Akbar et al., 1974 ; Schams and Schallenberger, 1976) with a secondary FSH peak of smaller magnitude occurring some $24 \mathrm{~h}$ later (Dobson, 1978). Plasma concentrations of oestradiol-17 $\beta$ rise over the four days before oestrus, with a peak occurring on the day before or on the day of oestrus behaviour (Glencross

(1) Present address: Meat and Livestock Commission, Queensway House, Bletchley, Milton Keynes, Great Britain. 
and Pope, 1981 ; Glencross et al., 1981a). Progesterone concentrations begin to fall from high luteal levels on about day 17 of the cycle and remain low until days 4 or 5 of the next cycle, at the time of formation of a new corpus luteum (Robertson, 1972).

The final stages of follicle maturation are considered to be under the control of the gonadotrophins, but until recently, the relationship between $\mathrm{LH}, \mathrm{FSH}$, oestradiol-17 $\beta$ and progesterone have not been described in detail for the cow. The present studies were undertaken to examine in more detail than previously, changes in plasma concentrations of these hormones during the luteal and follicular phases of the ovarian cycle.

\section{Materials and Methods.}

Ten Hereford $\times$ Friesian single-suckling beef cows each undergoing normal oestrous cycles were used for the study.

1. Experiment one. - Blood samples ( $2 \mathrm{ml}$ for $\mathrm{LH}$ assay) were taken from four cows on day 10 after oestrus (mid-luteal phase), at 10-min intervals for a $24-\mathrm{h}$ period. In addition, commencing on days $17,18,19$ and 20 after oestrus (follicular phase) blood samples $(2 \mathrm{ml})$, were taken at 10 -min intervals for 8 - $h$ periods (see table 1). During these intensive sampling periods, larger samples $(10 \mathrm{ml})$ were taken hourly to allow for assay of FSH and progesterone. Consecutive pairs of hourly samples were then pooled to assay for oestradiol-17 $\beta$. Subsequently, blood samples $(2 \mathrm{ml})$ were taken at 6 -hourly intervals for a further $48 \mathrm{~h}$ to determine the timing of the preovulatory LH surge.

2. Experiment two. - Blood samples were taken from six cows on day 5 ( $\mathrm{n}=$ 2 ; early luteal phase) or day 9 ( $n=4$; mid-luteal phase) of the oestrous cycle at 15-min intervals, for an 8 -h period (see table 2). Plasma was assayed for LH, FSH and progesterone.

Hormone assays. - Plasma progesterone and LH concentrations were assayed as described by Webb et al. (1977) and plasma FSH was assayed as described by Webb et al. (1980). The assay reliability criteria did not differ significantly from those previously published. Plasma concentrations of oestradiol-17 $\beta$ were measured using the original method of Glencross and Pope (1981) with the modifications described by Glencross et al. (1981b) and Peters (1984). The sensitivity, intraassay coefficient of variation (CV) and interassay CV were $1.60 \mathrm{pg} / \mathrm{ml}, 17.90 \%$ and $22.80 \%$ respectively.

Analysis of results. - Average hormone concentrations were calculated for each frequent sampling period to produce a representative hormone concentration for that occasion. Relationships between the different hormones were analysed by linear regression analysis. 
In experiment two, cross-correlation analyses were carried out between the plasma concentrations of $\mathrm{LH}, \mathrm{FSH}$ and progesterone using a variable lag between sample pairs. For example [LH] in sample $1 \mathrm{v}$. [FSH] in sample 1, [LH] in sample $1 \mathrm{v}$. [FSH] in sample 2, [ $\mathrm{LH}]$ in sample $2 \mathrm{v}$. [FSH] in sample 3 etc. A hormone pulse was defined as an increase of at least 50 per cent from the adjacent baseline value with at least two 10 or 15-min sample points on the downward limb (Riley et al., 1981).

\section{Results.}

Experiment one. - Evidence of overt oestrus and preovulatory-type LH surges (plasma concentrations of $12-18 \mathrm{ng} / \mathrm{ml}$ ) as determined by the 6-hourly sampling, occurred on day 21 after the first oestrus in Cows, $A, C$ and $D$ and on day 22 in Cow B. For convenience, hormone data for the follicular phase were standardised to the day on which the subsequent $\mathrm{LH}$ surge occurred (day 0 ). The mean plasma hormone concentrations and $\mathrm{LH}$ pulse amplitudes and frequencies for the five intensive sampling periods are shown in table 1. The decrease in mean plasma progesterone concentrations during the four follicular phase sampling periods (see table 1) was negatively correlated with rising plasma LH concentrations $(r=-0.99 ; P<0.001)$, LH pulse frequency $(r=-0.99$; $P<0.001)$ and plasma oestradiol- $17 \beta$ concentrations $(r=-0.957 ; P<0.001)$. The increasing plasma concentrations of $\mathrm{LH}$ and oestradiol-17 $\beta$ were also highly correlated $\langle r=0.927 ; P<0.001)$. Neither $L H$ pulse amplitude nor mean FSH concentrations changed significantly between any of the sampling periods (see table 1), except that there was a significant decrease in mean FSH concentrations between days 4 and 3 before the LH surge $(P<0.05)$.

The series of hormone profiles for Cow $D$ is shown in figure 1. In all four mid-luteal phase LH profiles, the baseline fluctuated markedly with an irregular pulse pattern compared to those taken in the follicular phase. However approximately six pulses were observed in each cow's profile during the 24-hour sampling period (see table 1). Hourly plasma FSH and oestradiol-17 $\beta$ concentrations fluctuated markedly during the mid-luteal sampling period but did not show any consistent pattern.

Experiment two. - Mean values for $\mathrm{LH}, \mathrm{FSH}$ and progesterone concentrations are shown in table 2 . $\mathrm{LH}$ concentrations fluctuated in a pulsatile manner. The LH pulse frequency of cows 26 and 36 on day 5 of the cycle (early luteal phase) was higher ( 6 to 7 pulses per $8 \mathrm{~h}$ ) than in the four cows sampled on day 9 (2 to 3 pulses per $8 \mathrm{~h}$; mid-luteal phase) except in one cow (no. 38) which still exhibited 6 pulses per $8 \mathrm{~h}$ (see table 2 and fig. 2). No attempt was made to quantify $\mathrm{FSH}$ and progesterone pulses (see Discussion). Results of cross correlation analyses between concentrations of the three hormones are shown in table 3, but showed no consistently significant relationships. 


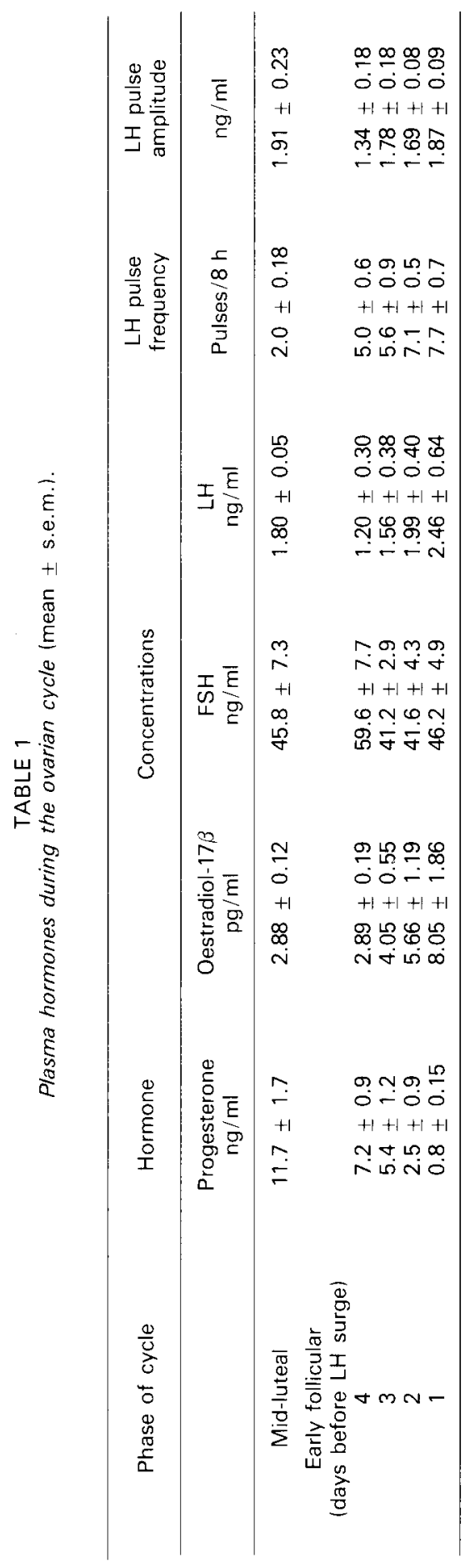



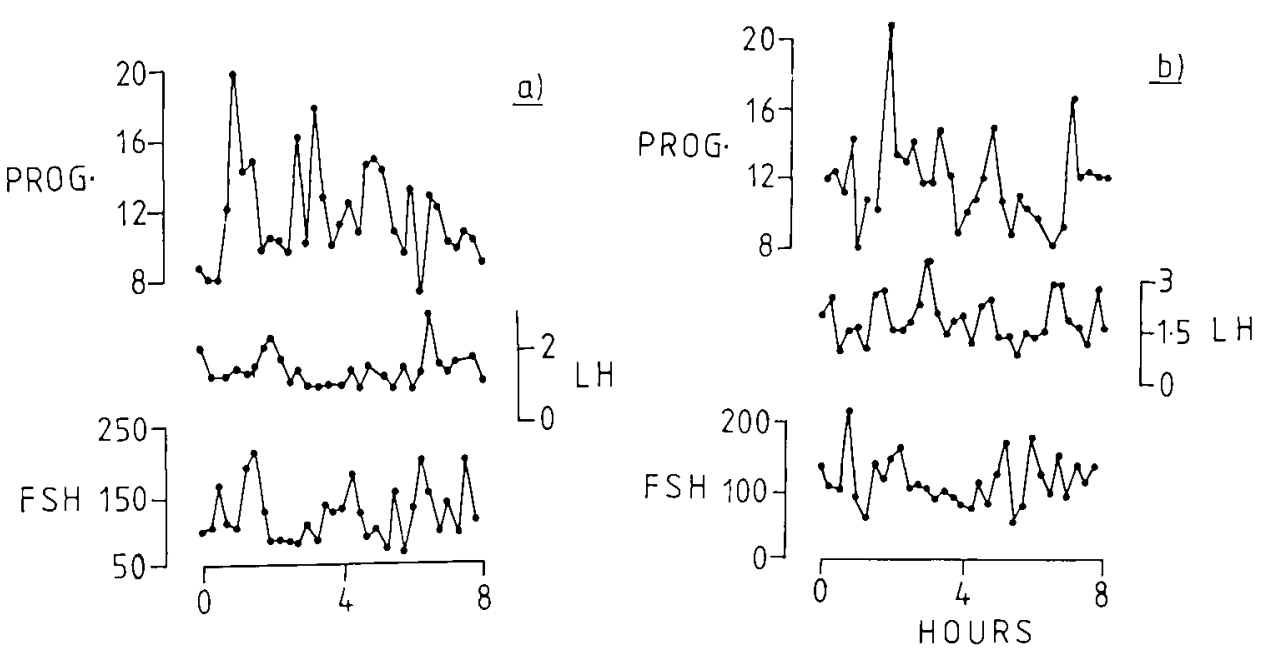

FIG, 2. - Plasma concentrations of progesterone, FSH and $L H(\mathrm{ng} / \mathrm{mll}$ in a) cow 37 and b) cow 38 , both on day 9 of the ovarian cycle (mid-luteal phase).

TABLE 3

Cross correlation coefficients between hormone concentrations in cows during the luteal phase of the ovarian cycle.

\begin{tabular}{|c|c|c|c|c|c|c|c|c|c|c|c|c|}
\hline \multirow[b]{2}{*}{ Cow No } & \multicolumn{2}{|c|}{ LH : FSH } & \multicolumn{2}{|c|}{ FSH: LH } & \multicolumn{2}{|c|}{ LH : Prog } & \multicolumn{2}{|c|}{ Prog : LH } & \multicolumn{2}{|c|}{ FSH : Prog } & \multicolumn{2}{|c|}{ Prog : FSH } \\
\hline & ${ }^{(1)} r \quad\langle 2)$ & lag & $r$ & lag & $r$ & lag & $r$ & $\operatorname{lag}$ & $r$ & lag & $r$ & lag \\
\hline 26 & -0.24 & 2 & 0.26 & 5 & -0.40 & 4 & - & - & -0.20 & 2 & $-0.39^{*}$ & 3 \\
\hline 36 & $-0.36^{*}$ & 5 & 0.23 & 5 & $0.35^{*}$ & 5 & $0.40^{*}$ & 8 & 0.25 & 6 & 0.28 & 7 \\
\hline 25 & $0.35^{*}$ & 4 & 0.23 & 7 & -0.31 & 8 & 0.28 & 2 & -0.31 & 2 & $0.43^{*}$ & 5 \\
\hline 31 & 0.31 & 1 & $0.41^{*}$ & 7 & - & - & $0.50^{*}$ & 12 & 0.19 & 2 & 0.22 & 2 \\
\hline 37 & & & $0.40^{*}$ & 2 & 0.27 & 5 & - & - & - & - & 0.24 & 2 \\
\hline 38 & 0.30 & 3 & 0.22 & 4 & $0.43^{*}$ & 2 & 0.25 & 6 & $0.46^{*}$ & 5 & 0.28 & 2 \\
\hline
\end{tabular}

* $r$ values $>0.35$ are significant at the $5 \%$ level.

$11\}_{r}=$ correlation coefficient.

${ }^{(2)} \mathrm{lag}=$ shift in sample no between the two hormone values.

\section{Discussion.}

Experiment one. - All cows underwent a 21-day cycle except Cow B which underwent the preovulatory LH surge approximately $24 \mathrm{~h}$ later than cows $A, C$ and $\mathrm{D}$. The timing of the $\mathrm{LH}$ surge has previously been shown to coincide approximately with behavioural oestrus (Schams et al., 1977) and the present data support this relationship. Plasma LH and oestradiol-17 $\beta$ concentrations increased during the follicular phase, in association with the fall in progesterone concentrations. It is generally accepted that the withdrawal of negative feedback due to decreasing progesterone concentrations following luteolysis, is followed by an increase in tonic $\mathrm{LH}$ release, occurring as a result of increasing $\mathrm{LH}$ pulse frequency (Schallenberger et al., 1984). Increasing LH concentrations are then considered to stimulate follicular oestradiol secretion. 
In the present study, the increase in mean LH concentrations during the follicular phase was reflected in an increase in LH pulse frequency to that of approximately one pulse per hour on the day before the preovulatory LH surge and oestrus (table 1). Hourly or more frequent pulses of LH are associated with this stage of the cycle in Holstein heifers (Rahe et al., 1980) and in sheep (Hauger, Karsch and Foster, 1977 ; Baird, 1978). We have also suggested that in the post-partum anoestrous cow there is a gradual increase towards an hourly $\mathrm{LH}$ pulse frequency, before the first ovulation occurs (Lamming et al., 1982). The frequency of LH pulses during the luteal phase of approximately one per four hours is in good agreement with that reported by Rahe et al. (1980).

In the present data, the LH pulse amplitude did not vary significantly with the stage of the cycle, in contrast to the report by Rahe et al. (1980) who classified $\mathrm{LH}$ pulses in the mid-luteal phase as high amplitude-low frequency. The fluctating LH baseline and generally less discrete pulses during the mid-luteal phase (see fig. 1), may reflect differences in breed, age, parity and/or environment between the two studies.

The rise in plasma oestradiol concentrations between days 17 and 20 of the cycle, is in agreement with the findings of Glencross et al. (1981a) and probably reflects an increased rate of secretion by the dominant ovarian follicle destined to ovulate (Hackett and Hafs, 1969 ; Schallenberger et al., 1984). Rising oestradiol concentrations are known to induce the preovulatory gonadotropin LH surge by a positive feedback effect (Kesner, Convey and Anderson, 1981).

Experiment two. - LH concentrations fluctuated in a pulsatile manner during both the early and mid-luteal phase and there was a tendency for LH pulse frequency to be lower in the mid-luteal phase. These results are in general agreement with those in Experiment one, althought the $\mathrm{LH}$ concentrations and pulse frequency tended to be higher in Experiment two. Consistent discrete pulses of FSH and progesterone analogous to those of LH were not observed. However, oscillations in the concentrations of these two hormones did occur, but most did not fulfil our previous definition of a pulse (Riley, Peters and Lamming, 1981), since there was often only a single elevated point between adjacent troughs. A pulsatile pattern of $\mathrm{FSH}$ secretion has been described in the cow (Walters, Schams and Schallenberger, 1984; Schallenberger et al., 1984 ; Walters and Schallenberger, 1984). The differences in FSH patterns between the two studies may reflect differences in the RIA procedures used. Walters et al. (1984) have also described discrete pulsatile patterns of progesterone during the luteal phase in the cow, but these were in samples taken from the posterior vena cava, therefore reflecting more directly, ovarian output of this steroid.

In that study there was a close correlation between vena cava FSH and progesterone concentrations. In the present study the measurement of these hormones in jugular blood may have precluded the finding of a similar relationship.

Based on both the present data and other studies it is concluded that : 1) LH pulse frequency is low (2 to 3 pulses per 8 hours in most cows) during the mid-luteal phase. As progesterone concentrations fall during luteolysis, the LH 
pulse frequency increases, stimulating follicle maturation and oestradiol production, which eventually culminates in the preovulatory gonadotrophin surge and ovulation. As progesterone concentrations rise during the next luteal phase the $\mathrm{LH}$ pulse frequency is reduced.

2) $\mathrm{FSH}$ concentrations appear to change little throughout the cycle, except for a significant decrease during luteolysis. FSH may be a factor involved in regulating pulsatile progesterone secretion since in one study their pulse frequencies were similar and highly correlated (Walters et al., 1984).

Although short-term changes were not measured in this study, others have demonstrated pulsatile patterns of oestradiol-17 $\beta$ albeit in the posterior vena cava. The frequency appears to be related directly to that of LH (Walters et al., 1984).

Reçu en mars 7985. Accepté en juin 1985

Acknowledgements. - The author gratefully acknowledges the financial assistance of the Agriculture and Food Research Council and the Meat and Livestock Commission. The valuable help of $\mathrm{Mr}$ and Mrs R. Temple and Dr G. M. Riley is also acknowledged.

Résumé. Etude des diagrammes hormonaux chez la vache durant le cycle oestral.

Au cours de deux expériences, les concentrations plasmatiques de différentes hormones ont été déterminées chez la vache durant le cycle cestral. Pendant la phase lutéale, la fréquence des "pulses» de LH est faible (2 à 3 par période de $8 \mathrm{~h}$ ). II n'existe pas de corrélation nette entre les concentrations de $\mathrm{LH}$, de $\mathrm{FSH}$ et de progestérone. Pendant la lutéolyse, la chute des taux de progestérone s'accompagne d'une élévation des taux d'œstradiol $17 \beta$ et de LH. La fréquence des "pulses" de cette dernière hormone atteint presque 1 "pulse » par heure un jour avant la décharge préovulatoire.

\section{References}

AKBAR A. M., REICHERT L. E. Jr., DUNN T. G., KALTENBACH C. C., NISWENDER G. D., 1974. Serum levels of FSH during the bovine oestrous cycle. J. anim. Sci., 39, 360-365.

BAIRD D. T., 1978. Local utero-ovarian relationships, 217-233. In D. B. CRIGHTON, N. B. HAYNES, G. R. FOXCROFT and G. E. LAMMING. Control of ovulation. Butterworths, London.

CHRISTENSEN D. S., HOPWOOD M. L., WILTBANK J. N., 1974. Levels of hormones in the serum of cycling beef cows. J. anim. Sci., 38, 577-583.

DOBSON H., 1978. Plasma gonadotrophins and oestradiol during oestrus in the cow. J. Reprod. Fert., 52, 51-53.

GLENCROSS R. G., POPE G. S., 1981. Concentrations of oestradiol-17 $\beta$ and progesterone in the plasma of dairy heifers before and after clorosterol-induced and natural luteolysis and during early pregnancy. Anim. Reprod. Sci., 4, 95-106.

GLENCROSS R. G., ESSLEMONT R. J., BRYANT M. J., POPE G. S., 1981a. Relationships between the incidence of preovulatory behaviour and the concentrations of oestradiol-17 $\beta$ and progesterone in bovine plasma. Appl. anim. Ethol., 7, 141-148.

GLENCROSS R. G., ABEYWARDENE S. A., CORNEY S. J., MORRIS H. B., 1981b. The use of oestradiol-17 $\beta$ antiserum to extract oestradiol-17 $\beta$ from biological fluids. $J$. Chromatogr. biomed. Applic., 223, 193-197. 
HACKETT A. J., HAFS H. D., 1969. Pituitary and hypothalamic endocrine changes during the bovine oestrous cycle. J. anim. Sci, 28, 531-535.

HANSEL W., CONCANNON D. W., LUKASZEWSKA J. H., 1973. Corpora lutea of the large domestic animals. Biol. Reprod., 8, 222-245.

HAUGER R. L., KARSCH F. J., FOSTER D. L., 1977. A new concept for control of the oestrous cycle of the ewe based on the temporal relationships between luteinizing hormone, oestrous and progesterone in peripheral serum and evidence that progesterone inhibits tonic LH secretion. Endocrinology, 101, 807-817.

HENRICKS D. M., DICKEY J. F., NISWENDER G. D., 1970. Serum luteinizing hormone and plasma progesterone levels during the oestrous cycle and early pregnancy in cows. Biol. Reprod., 2, 345-351.

KESNER J. S., CONVEY E. M., ANDERSON C. R., 1981. Evidence that oestradiol induces the preovulatory $\mathrm{LH}$ surge in cattle by increasing pituitary sensitivity to $\mathrm{LHRH}$ and then increasing LHRH release. Endocrinology, 108, 1386-1391.

LAMMING G. E., PETERS A. R., RILEY G. M. FISHER, M. W., 1982. Endocrine regulation of post-partum function, 148-172. In H. KARG, E. SCHALLENBERGER, Factors influencing fertility in the post-partum cow, Martinus Nijhoff. The Hague.

PETERS A. R., 1984. Effect of exogenous oestradiol-17 $\beta$ on gonadotrophin secretion in post-partum beef cows. J. Reprod. Fert, 72, 473-478.

RAHE C. H., OWENS R. E., FLEEgER J. L., NEWTON H. J., HARMS P. G., 1980. Pattern of plasma luteinizing hormone in the cyclic cow: dependance upon the period of the cycle. Endocrinology, 107, 498-503.

RILEY G. M., PETERS A. R., LAMMING G. E., 1981. Induction of pulsatile LH release, FSH release and ovulation in post-partum acyclic beef cows by repeated small doses of GnRH. J. Reprod. Fert., 63, 559-565.

ROBERTSON H. A., 1972. Sequential changes in plasma progesterone in the cow during the oestrous cycle, pregnancy, at parturition and post-partum. Can. J. anim. Sci, 52, 645-658.

SCHALLENBERGER E., SCHAMS D., BULLERMANN B., WALTERS D. L., 1984. Pulsatile secretion of gonadotrophins, ovarian steroid and ovarian oxytocin during prostaglandin-induced regression of the corpus luteum in the cow. J. Reprod. Fert., 71, 493-501.

SCHAMS D., KARG H., 1969. Zeirlicher Verlauf und analytische Erfassbarkeit des endogen bzw. exogen erhöhten Blutspiegels an Luteinisierungshormon beim Rind. Zuchthygiene, 4, 61-64.

SCHAMS D., SCHALLENBERGER E., 1976. Heterologous radioimmunoassay for bovine folliclestimulating hormone and its application during the oestrous cycle in cattle. Acta endocrinol. Copenh., 81, 461-473.

SCHAMS D., SCHALLENBERGER E., HOFFMAN B., KARG H., 1977. The oestrous cycle of the cow: hormonal parameters and time relationships concerning oestrus, ovulation and electrical resistance of the vaginal mucus. Acta endocrinol. Copenh., 86, 180-192.

SNOOK R. B., SAATMAN R., HANSEL W., 1971. Serum progesterone and luteinizing hormone levels during the bovine oestrous cycle. Endocrinology, 88, 678-686.

SWANSON L. V., HAFS H. D., 1971. LH and prolactin in blood serum from oestrus to ovulation in Holstein heifers. J. anim. Sci, 33, 1038-1041.

WALTERS D. L., SCHALLENBERGER E., 1984. Pulsatile secretion of gonadotrophins, ovarian steroids and ovarian oxytocin during the periovulatory phase of the oestrous cycle of the cow. J. Reprod. Fert., 71, 503-512.

WALTERS D. L., SCHAMS D., SCHALLENBERGER E., 1984. Pulsatile secretion of gonadotrophins, ovarian steroids and ovarian oxytocin during the luteal phase of the oestrous cycle of the cow. J. Reprod. Fert., 71, 479-491.

WEBB R., LAMMING G. E., HAYNES N. B., HAFS H. D., MANNS J. G., 1977. Response of cyclic and post-partum suckled cows to injection of synthetic LHRH. J. Reprod. Fert., 50, 203-210.

WEBB R., LAMMING G. E., HAYNES N. B., FOXCROFT G. R., 1980. Plasma progesterone and gonadotrophin concentrations and ovarian activity in post-partum dairy cows. J. Reprod. Fert., 59, 133-143. 